\title{
Cagnin e as narrativas gráficas: histórias em quadrinhos como objeto de pesquisa
}

\author{
Edilaine Correa Gonçalves
}

\author{
CAGNIN, A. L \\ Os quadrinhos: um estudo \\ abrangente da arte sequencial, \\ linguagem e semiótica \\ ed. São Paulo: Criativo, \\ 288 p., 2015.
}

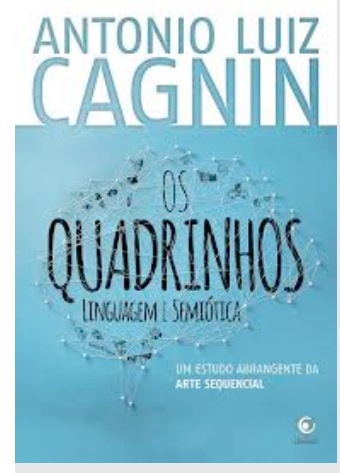

Resumo: O título recentemente publicado é fruto de trabalho acadêmico de mestrado defendido, em 1974, por Antonio Luiz Cagnin quando, inovadoramente, procurava sistematizar o processo de leitura e reconhecimento das histórias em quadrinhos como forma de expressão, diferenciando-as de outras modalidades narrativas, e destacando o emprego de elementos característicos que possibilitam ao leitor criar os nexos entre imagens e textos, dispostos de forma a propiciar a geração de sentidos.

Palavras-chave: histórias em quadrinhos; linguagem narrativa; comunicação visual; semiologia.

Abstract: Cagnin and the graphic narratives: comics as research theme - This book is the outcome of a Master degree presented by Antonio Luiz Cagnin in 1974. He intended to systematically organize the reading and reception process of the comics as a way of expression, differently from other narrative models. He highlighted the use of features that allow the reader to create links among images and texts, in such a way to permit meaning construction.

Keywords: comics; narrative language; visual communication; semiology. 
O autor Antonio Luiz Cagnin foi um dos pesquisadores pioneiros a defender trabalho acadêmico, nos idos da década de 70, sobre histórias em quadrinhos, do ponto de vista semiótico, desenvolvendo processo sistematizado para análise das mesmas, de forma a diferenciá-las de outras modalidades narrativas.

Em questões que procuram verificar teorias sobre a possível hegemonia das palavras em detrimento das imagens, o autor exemplifica as diferenças entre conceitos, como por exemplo, de imagens acústica e mental, processos de significação de sinais, naturais ou artificiais, entre outros. Para a investigação do sistema de decifração de HQs, consultou teóricos diversos como Saussure, Greimas, Barthes, Prieto, Jakobson, Pierce, Eco, Lévi-Strauss, Todorov, além de outros, todos para aprofundar a reflexão sobre significantes e significados, ou da própria semiótica do signo visual que participam dessa linguagem e, que parece remeter, à primeira vista, a algo simples, sendo na verdade, objeto complexo com facetadas camadas ou possibilidades de leituras.

Este livro é resultado de um dos trabalhos pioneiros no território brasileiro ao investigar os processos de reconhecimento, leitura e identificação de elementos narrativos, presentes na linguagem das histórias em quadrinhos, produto cultural híbrido que mistura imagens (personagens desenhados, balões etc.) com inclusão de textos ou onomatopeias, promovendo certa dinâmica visual com sugestão de leitura articulada, segundo o autor, por três formas: icônica (traços, pontos, hachuras etc.) que formam as figuras; por unidades dinâmicas sugeridas para sua leitura, e por sequências que, por sua vez, formam episódios e toda a história propriamente dita.

O trabalho acadêmico foi publicado, primeiramente, em 1975, pela editora Ática, sem reedição posterior, tornando-se título raro até essa nova edição revista pela Editora Criativo, que vivifica a pesquisa em questão, trazendo ao público leitor, ou pesquisador, uma versão atualizada da pesquisa referenciada. Apresenta-se como leitura obrigatória para pesquisadores em comunicação, tendo recebido, inclusive, menção na Revue Communications, caracterizado como:

[...] livro de semiótica dos quadrinhos que constitui uma excelente síntese de pesquisas européias. Em sua última parte é apresentada uma aproximação entre a estrutura da narração figurativa adaptando as sequências das imagens aos procedimentos da descrição em gráficos desenvolvidos pela gramática generativa.

O livro apresenta quatro capítulos originais da dissertação, discorrendo sobre: histórias em quadrinhos, leituras e elementos constituintes; a imagem, no que diz respeito à percepção, diferentes ou complementares conceitos, tempo e unidades narrativas e sua estrutura, segundo Propp, meios expressivos gráficos, signos, planos visuais, funções da linguagem textual, que dirigem o leitor à fixação do significado ou formas de representação e análises. Discursa também sobre a tipologia icônica e análise de diversos

1 Bibliographie. In: Revue Communications, 1976, p. 243. 
gêneros e tipos de histórias em quadrinhos para exemplificar como o autor sistematizou seu trabalho para observar o objeto, em vários planos gerais e panorâmicos, de alguns quadrinhos sem texto, com texto, de um só quadrinho, tiras etc. Além da pesquisa, somam-se depoimentos de pesquisadores atuais, renomados da área, que atestam o valor dessa obra, tais como Waldomiro Vergueiro, Sonia M. Bibe Luyten, Gonçalo Jr, Roberto Elísio dos Santos, Nobu Chinen entre outros, alguns deles, seus alunos. A obra tem apresentação de André Campos de Carvalho, mestre em Comunicação e Semiótica pela PUC-SP com pesquisa sobre o objeto quadrinhos de Carl Barks.

Desta forma, uma grande compilação de informações, hipóteses e perguntas apresentam os quadrinhos como:

[...] substância de expressão da narrativa formada por dois códigos, Imagem - signo visual analógico ao código iconográfico e Texto - representado na palavra escrita dos balões, legendas e título pelo narrador como dois elementos [...] contidos na moldura (o quadro) - signo digital, convencional criado para significar, como índice, os limites da imagem e do texto formando a unidade narrativa iconográfica articulável. (CAGNIN, 2014, p. 178)

Essa nova edição, atualizada e ampliada, apresenta, ainda, entrevista inédita com o autor que, infelizmente, não pode acompanhar seu relançamento, pois faleceu em outubro de 2013, aos 83 anos de idade.

Edilaine Correa é Mestre em Comunicação e Semiótica pela PUC-SP, participa do Grupo de Pesquisas em Histórias em Quadrinhos da ECA USP como pesquisadora e colaboradora do blog e fanpage do grupo.

edi_puc@hotmail.com.

\section{Referências}

REVUE Communications. Éditeur Le Seuil. 1976. Disponível em: http://www.persee.fr/web/revues/home/prescript/ article/comm_0588-8018_1976_num_24_1_1373. Acesso em: set. de 2015. 